\title{
ПРАВО НА СПРАВЕДЛИВИЙ СУД: УКРАЇНСЬКИЙ КОНТЕКСТ
}

\author{
КОТЬКО Марія Ігорівна - студентка 1 курсу 6 групи факультету Інституту \\ підготовки кадрів для органів юстиції України Національного юридичного \\ університету імені Ярослава Мудрого \\ ORCID ID: https://orcid.org/0000-0002-1460-2200 \\ УДК 340.132 \\ DOI 10.32782/NP.2021.2.4
}

Право на справедливий суде основоположною гарантією захисту прав і свобод людини. y статті досліджено становлення концепиї права на справедливий суд від ідеї до юридичного закріплення на міжнародному рівні. Проведено аналіз борм, видів та правових наслідків порушення права на справедливий суд, як в Україні, так $і$ в зарубіжних країнах. Виявлено основні причини порушення права на справедливий суд. Запропоновано шляхи та механізми вдосконалення украӥнського законодавства для вирішення системної проблеми порушення права на справедливий суд.

\section{Постановка проблеми}

На сьогодні проблема невиконання судових рішень ЕСПл Україною стала системною, що порушує Конвенцію про захист прав людини і основоположних свобод, а саме право на справедливий суд. У законодавстві України відсутні ефективні засоби правового захисту права на справедливий судовий розгляд, що порушує основні гарантії захисту прав людини. На розгляді суду залишається велика кількість скарг, які не виконуються через бездіяльність держави та кількість яких з роками тільки збільшується.

\section{Мета статті}

Головною метою роботи є дослідження питання становлення концепції права на справедливий суд як основоположної гарантії прав і свобод людини, аналіз судової практики $6 С П \curlywedge$, вивчення першопричин проблеми невиконання судових рішень в Україні та надання пропозицій щодо впровадження ефективних механізмів боротьби із невиконанням судових рішень в Україні.

\section{Аналіз останніх досліджень i публікацій}

Питанням змістовного тлумачення права на справедливий суд знайшла своє відображення у наукових працях багатьох учених-правників, серед яких I. Гриценко, М. Ентін, В. Комаров, О. Кучинська, У. Коруц, М. Погорецький, С. Погребняк, Н. Сакара, Н. Сиза, О. Ткачук, Т. Цувіна та ін.

\section{Виклад основного матеріалу}

Право на справедливий суд є основоположною гарантією захисту прав і свобод людини. Від ефективної реалізації права на справедливий суд залежить загальна система функціонування права.

Фундаментальним для поняття права на справедливий суд є категорія справедливості. У юридичному сенсі справедливість розглядають як властивість права, виражену, зокрема, в рівному юридичному масштабі поведінки і у пропорційності юридичної відповідальності вчиненому правопорушенню [1] або як розмірність, рівність у правовому статусі суб'єктів[2].

3 найдавніших часів справедливість розглядалась як ключова категорія при здійсненні правосуддя. Так, у стародавніх східних державах монарх вважався носієм вищої справедливості, творцем волі богів 
і міг віддати «всякому скаржнику справедливість». У Стародавньому Сгипті і Стародавній Індії судове рішення сприймалося як акт справедливості, який відбувається за допомогою законів, а іноді й за участю богів. В одному 3 найдавніших законодавчих кодексів Закони Хамурапі закріплювалося: «Щоб сильний не пригноблював слабкого, щоб надати справедливість сироті та вдові, щоб у Вавилоні - місті, главу якого вознесли Анум і Елліль, в Есагіле - храмі, фундамент якого міцно встановили, точно небеса і земля, - судити суд країни, виносити рішення країни, притисненому надати справедливість» [3]. У Стародавньому Сгипті судове рішення вважалося ідеалом суворої справедливості, в інструкціях фараон наставляв візира, щоб той судив усі випадки за законом, поважаючи справедливість. Античні мислителі так само акцентували важливість поняття справедливого суду, так Аристотель зазначав: «Іти до суду - значить звертатися до справедливості, оскільки суддя прагне бути ніби уособленою справедливістю; до того ж, люди шукають неупередженого суддю» [4].

3 роками ідея права на справедливий суд розвивалася і була кодифікована на міжнародному рівні в Загальній декларації прав людини. Так, ст. 8 Декларації передбачає, що кожна людина має «право на ефективне поновлення у правах компетентними національними судами в разі порушення іiі основних прав, наданих їй конституцією або законом». Сучасна інституціоналізація права на справедливий судовий розгляд на міжнародному рівні відбулася з прийняттям Конвенції про захист прав людини і основоположних свобод 1950 року (далі- Конвенція), де у п. 1 ст. 6 закріплено право кожного на справедливий i публічний судовий розгляд його справи упродовж розумного строку незалежним і безстороннім судом, встановленим законом, який вирішить спір щодо його прав та обов'язків цивільного характеру або встановить обгрунтованість будь-якого висунутого проти нього кримінального обвинувачення, що в подальшому вплинуло на законодавство європейських країн.
Також, право на справедливий судовий розгляд знайшло своє закріплення на національному рівні у Сполучених Штатах Америки в Біллі про права, де у 6 поправці зазначено, що «у всіх випадках кримінального переслідування обвинувачений має право на швидкий і публічний суд неупереджених присяжних того штату та округу, де було скоєно злочин; причому цей округ повинен бути заздалегідь встановлений законом; обвинувачений має право на інформування про характер і підстави звинувачення, на очну ставку з свідками, які показують проти нього, на примусовий виклик свідків, що показують на його користь, і на допомогу адвоката для свого захисту».

Натомість, право на справедливий суд не знайшло свого безпосереднього текстуального відображення в Конституції України. Проте, у ст. 55 зазначено: «Права i свободи людини і громадянина захищаються судом. Кожному гарантується право на оскарження в суді рішень, дій чи бездіяльності органів державної влади, органів місцевого самоврядування, посадових і службових осіб». Також контекстуально 3 деяких статей Розділів 1, 2 Конституції України можна виділити елементи права на справедливий суд. Наприклад:

- ст. 8 (Звернення до суду для захисту конституційних прав і свобод людини i громадянина безпосередньо на підставі Конституції України гарантується);

- ст. 32 (Кожному гарантується судовий захист права спростовувати недостовірну інформацію про себе і членів своєї сім'і та права вимагати вилучення будьякої інформації, а також право на відшкодування матеріальної і моральної шкоди, завданої збиранням, зберіганням, використанням та поширенням такої недостовірної інформації);

- $\quad$ ст. 63 (Підозрюваний, обвинувачений чи підсудний має право на захист).

17 липня 1997 року Україна ратифікувала Конвенцію, визнавши обов'язкову юрисдикцію Европейського суду з прав людини, та закріпивши в Україні на законодавчому рівні механізми, які регулюють забезпечення виконання судових рішень національними судами. Так, наприклад, відповідно до ст. 9 Конституції України чинні міжнародні 


\section{Теорія, історія держави і права, конституційне право}

договори, згода на обов'язковість яких надана Верховною Радою України, є частиною національного законодавства України. Також ст. 1 Закону України «Про виконання рішень та застосування практики Свропейського суду з прав людини» закріплює необхідність виконання рішення за допомогою запровадження заходів індивідуального характеру: відшкодування шкоди, заподіяної порушенням права, гарантованого Конвенцією, а також відновлення порушеного права, якщо це можливо (додаткові заходи індивідуального характеру)[5].

Aле проаналізувавши рішення $Е С П \lambda з$ 2004 року проти України, можна зробити висновок, що в Україні набула систематичного характеру проблема порушення п.1 ст. 6, ст. 13 Конвенції та статті 1 протоколу № 1 до Конвенції, невиконання судових рішень. Про що свідчать пілотні рішення по справах «Іванов проти України» та «Бурмич та інші проти України».

Першою ознакою існування проблеми невиконання судових рішень було у справі «Кайсин та інші проти України», у якій було запропоновано дружне врегулювання. У справі «Жовнер проти України» було вперше офіційно зафіксовано цю проблему 3 погляду Конвенції. А вже у 2004 році Судом було встановлено вперше порушення, пов'язане 3 невиконання рішень національних судів України. Після цього було винесено низку судових рішень в аналогічних справах.

Для врегулювання такої комплексної проблеми в судочинстві України 15 жовтня 2009 року Судом було винесено пілотне рішення по справі «Іванов проти України», у якому зазначалося, що проблема тривалого виконання остаточних національних рішень та відсутності ефективного національного засобу правового захисту для їх виправлення стала повторювальною, яка, у свою чергу, стає джерелом найбільш частих порушень Конвенції, так понад 300 справ надійшло до Суду з 2004 року саме через порушення ст. 6 Конвенції. Як зазначено Судом, справа «Іванов проти України» демонструєте невирішення зазначених проблем Україною, незважаючи на чітку практику Суду. Тому було винесено рекоменда- ції стосовно того, як вирішити ці проблеми, а саме: Україна повинна впровадити у свій правовий порядок ефективний засіб правового захисту, який забезпечуватиме адекватну та достатню компенсацію у випадку невиконання або несвоєчасного виконання рішень.

У результаті не врегулювання Україною проблеми невиконання судових рішень, після пілотного рішення за період 2013-2017 років до Суду надійшло 12143 скарги, які стосуються порушення Україною п. 1 ст. 6 та ст. 13 Конвенції. Для ефективного вирішення проблеми рішенням Великої Палити 2017 року у справі «Бурмич та інші проти України» було встановлено необхідність об'єднати ці п’ять заяв та 12143 заяви, що знаходяться на розгляді в Суді, згідно 3 Правилом 42 § 1 Регламенту Суду з огляду на спільне походження цих заяв із системного порушення Конвенції. У рішенні було встановлено, що Україна не вирішила систематичну проблему щодо невиконання рішень національних судів; реформи, які були проведені, мали загальний характер і призвели лише до збільшення числа скарг. Також Судом було зазначено, що їх кількість у подальшому може збільшуватися; через те, що Суд не є судом першої інстанції, усі справи видаляються з бази суду і передаються на розгляд Комітету Міністрів, а порушення в них визнається автоматично; рішення національних судів мають бути виконані під контролем Комітету Міністрів. При цьому у майбутньому Суд закріплюе за собою право передавати такі типові справи до Комітету Міністрів, у яких уже визнано порушення автоматично та якщо заявниками були дотримані формальні критерії прийнятності.

Переважна кількість скарг проти України стосується надмірної тривалості досудового слідства у кримінальних провадженнях, судового розгляду чи виконання рішень національних судів та відсутності правових засобів для вирішення цієї проблеми на національному рівні. Як зазначає С.В. Шевчук, найбільша кількість справ проти України за останні роки стосується саме порушення національними судами права на справедливий судовий розгляд протягом розумного строку[6]. 
Відповідно до ст. 6 Конвенції розумний строк $є$ обов'язковим при розгляді цивільних, кримінальних та адміністративних справ. Так, у цивільних та адміністративних справах перебіг розумного строку починається 3 моменту відкриття провадження, а в окремих випадках 3 моменту виникнення права на подання позову.

Стосовно практики Суду в кримінальних справах, розумний строк визначається 3 дня, коли особі було пред'явлено обвинувачення. У Конституцію України з 02.06.2016 були внесені зміни щодо правосуддя відповідно до яких у п. 7 с. 129 зазначається, що основними засадами судочинства є розумні строки розгляду справи судом, натомість, чіткого тлумачення поняття "розумні строки” в контексті Конституції України на разі немає. Варто зазначити, що Конституційний Суд тлумачить поняття «розумний строк», але в контексті досудового слідства в рішенні у справі про розгляд судом окремих постанов слідчого і прокурора, зазначаючи, що поняття «розумний строк досудового слідства» $є$ оціночним, тобто таким, що визначається у кожному конкретному випадку з огляду на сукупність усіх обставин вчинення і розслідування злочину (злочинів). Визначення розумного строку досудового слідства залежить від багатьох факторів, включаючи обсяг і складність справи, кількість слідчих дій, число потерпілих та свідків, необхідність проведення експертиз та отримання висновків тощо[7]. Також для забезпечення виконання судових рішень у розумні строки повинні бути передбачені ефективні засоби правового захисту, як це вимагається ст. 13 Конвенції.

Практика зарубіжних держав, у першу чергу Італії, Польщі, Словенії, Хорватії, визначає основні способи вирішення проблеми порушення п. 1 ст. 6 та ст. 13 Конвенції, зокрема пришвидшувальних, мета яких полягає у впливі на термін розгляду справи за допомогою скарги або клопотання про прискорення розгляду справи до голови суду; та компенсаторних, сутність яких полягає у відшкодуванні компенсацій за вже порушені права при судовому розгляді за допомогою подачі скарги або позову. Для більшої ефективності захисту права на су- довий розгляд у розумні строки зарубіжні країни використовують обидва способи у поєднанні.

Так, в Італії 24 березня 2001 року ухвалено Закон «Пінто», який запроваджує компенсаторний засіб вирішення спорів щодо розумної тривалості судового розгляду на національному рівні. Зокрема, передбачає можливість подання заяви про відшкодування шкоди за порушення розумного строку судового розгляду. Так, скарга подається протягом провадження або протягом шести місяців 3 дня набрання законної сили остаточного рішення суду [8].

Стосовно запровадження засобу правого захисту права на справедливий судовий розгляд у розумні строки в Польщі, то він відрізнявся від попереднього. Так, у 2004 році в Польщі набрав чинності Закон «Про скарги на порушення права сторони на розгляд без необгрунтованої затримки судового розгляду», який передбачає відповідальність за затримки під час судового розгляду справи. Законом було передбачено право подання скарги, стосовно того, що провадження по справі триває довше, ніж це потрібно для з'ясування фактичних та правових питань, які мають бути встановлені для правильного вирішення справи чи виконання рішення суду. Крім того, відповідно до Закону суд може зобов'язати Державне казначейство виплатити певну суму компенсацій, якщо така вимога вказана у скарзі [9].

Ще одним прикладом успішного механізму захисту права на справедливий судовий розгляд у розумний строк було прийняття Хорватією у 2005 році нового «Акту про суди», який містить главу «Захист права на справедливий судовий розгляд протягом розумного строку», у котрій закріплюється право сторони, яка вважає, що ії права були порушені, подати вимогу про захист цього права до суду вищої інстанції, а кінцевим засобом захисту є конституційна скарга до Конституційного Суду.

У 2006 році у Словенії було прийнято «Акт про захист права на справедливий судовий розгляд без неналежних затримок», який передбачає два способи правового захисту, один з яких спрямований на при- 


\section{Теорія, історія держави і права, конституційне право}

швидшення процесу, це так звана «наглядова скарга», мається на увазі, що сторона, яка вважає, що її право було порушено, має право подати наглядову скаргу голові суду, у якому розглядається іï справа, а інший компенсаторного характеру у формі позову про порушення права.

Виходячи 3 досвіду зарубіжних країн, слід зазначити, що врегулювання проблеми невиконання судових рішень стає першочерговою задачею для вирішення уповноваженими органами, з метою забезпечення ефективного захисту прав і свобод людини, гарантованими Конвенцією.

Варто зазначити, що на вирішення проблеми невиконання судових рішень впливає забезпечення діяльності судової влади, наприклад, несформованість вищої кваліфікаційної комісії суддів, хоча, Вища рада правосуддя оголосила про початок конкурсу до складу ВККСУ з 26 грудня 2019 року. 37 листопада 2019 року набрав чинності Закон України № 193-IX, у якому було зазначено про припинення повноважень всього складу ВККСУ, між тим, без чинної ВККСУ, яка відповідає за добір кандидатів на суддівські посади та кваліфікаційне оцінювання суддів, неможливо заповнити вакансії в судах, кількість яких уже сягає близько двох тисяч. Через брак суддів справи у судах чекають на вирішення роками. Це фактично позбавляє громадян України доступу до правосуддя[10].

\section{Висновки і пропозиції}

Для вирішення системної проблеми в Україні порушення п. 1 ст. 6 Конвенції та невиконання судових рішень слід врахувати досвід зарубіжних країн. Зокрема, закріпити на законодавчому рівні комплексний ефективний засіб правового захисту права на справедливий судовий розгляд упродовж розумного строку, що містив би пришвидшувальний та компенсаторний механізми вирішення проблеми. Виходячи 3 вищезазначеного, слід вказати, що однією 3 першопричин невиконання судових рішень 6 невизначеність поняття розумних строків, яке закріплено в п. 7 ст. 129, тому слід звернутися до Конституційного Суду України з конституційними поданням щодо офіційного тлумачення положення п. 7 ст. 129 Конституції України. Також проаналізувавши текст Конституції України, варто зазначити, що окрема стаття, у якій закріплювалися б основні елементи права на справедливий суд, у ній відсутня. Вбачаємо доцільним конкретизувати загальний найбільш принциповий перелік елементів права на справедливий суд, який може не бути вичерпним, втім, здатний виступати ідентифікатором ефективного судового захисту прав та свобод людини і громадянина.

\section{Мiтература}

1. Про призначення судом більш м'якого покарання: рішення Конституційного суду України від 02.11.2004. № 15рп/2004. Офіційний вісник України. 2004. № 45. Ст. 2975.

2. Про податкову заставу: рішення Конституційного суду України від 24.03.2005 № 2-рп/2005. Офіційний вісник України. 2005. № 13. Ст. 674.

3. Законы Хаммурапи. URL: http:// www.hist.msu.ru/ER/Etext/hammurap.htm.

4. Грень Н.M. Генезис права на справедливий суд. Науковий вісник Міжнародного гуманітарного університету. 2015. № 13. С. 22-24.

5. Закону України про виконання рішень та застосування практики Европей-

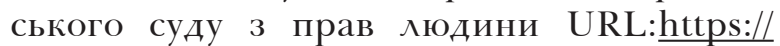
zakon.rada.gov.ua/laws/show/3477-15\#Text

6. Захист права на додержання розумних строків судового провадження: європейський досвід та українські реалії // Вiсник Верховного Суду України. - 2006. № 8. - c. 31-36.

7. Каталог юридичних позицій Конституційного Суду України (1997-2020 роки), 4. Права, свободи і обов'язки людини і громадянина, 4.3. Громадянські та політичні права, 4.3.9. Право на судовий захист, 4.3.9.6. Судочинство протягом розумного строку URL: https://ccu. gov.ua/storinka-knygy/4396-sudochynstvoprotyagom-rozumnogo-stroku

8. Crisafulli F. The Italian experience / F. Crisafulli // The improvement of domestic remedies with particular emphasis on cases of 
unreasonable length of proceedings. - Counsil of Europe. - P. 38-47 14. Fabri M. The Italian maze towards trials within reasonable time / M. Fabri// The right to trial within a reasonable time and short-term reform of the European Court of Human Rights: Round Table organized by the Slovenian Chairmanship of the Committee of Ministers of the Council of Europe, Bled, Slovenia, 21-22 September 2009. - Ljubljana : Ministry of Foreign Affairs: Ministry of Justice, 2009. - P. 125-148

9. Wołąsiewicz J. The Polish experience of the establishment of an effective remedy against the excessive length of proceedings / J. Wołąsiewicz // The right to trial within a reasonable time and short-term reform of the European Court of Human Rights: Round Table organized by the Slovenian Chairmanship of the Committee of Ministers of the Council of Europe. - Ljubljana : Ministry of Foreign Affairs: Ministry of Justice, 2009 . P. 24-27.

10. https://hcj.gov.ua/news/vyshcharada-pravosuddya-sformuvaty-vkksumozhlyvo-lyshe-pislya-vnesennya-zmin-dozakonodavstva

11. Конвенція про захист прав людини і основоположних свобод. URL: https:// zakon.rada.gov.ua/laws/show/995_004\# Text

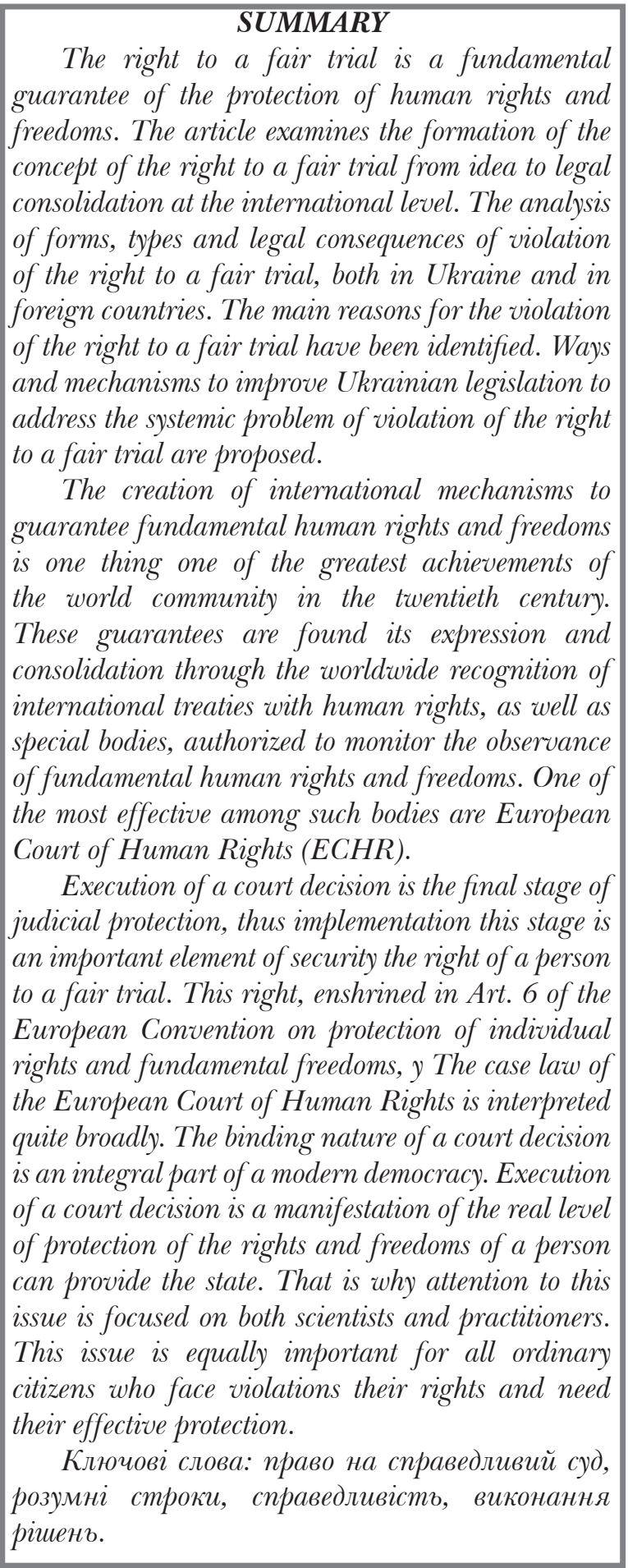

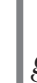

